\title{
Development and Characterization of Norite-Based Cementitious Binder from an Ilmenite Mine Waste Stream
}

\author{
Mahmoud Khalifeh, ${ }^{1}$ Arild Saasen, ${ }^{1}$ Helge B. Larsen, ${ }^{2}$ and Helge Hodne ${ }^{1}$ \\ ${ }^{1}$ Department of Petroleum Engineering, University of Stavanger, 4036 Stavanger, Norway \\ ${ }^{2}$ Department of Mathematics and Natural Sciences, University of Stavanger, 4036 Stavanger, Norway
}

Correspondence should be addressed to Mahmoud Khalifeh; mahmoud.khalifeh@uis.no

Received 6 May 2017; Revised 5 July 2017; Accepted 20 July 2017; Published 23 August 2017

Academic Editor: Kedsarin Pimraksa

Copyright ( 2017 Mahmoud Khalifeh et al. This is an open access article distributed under the Creative Commons Attribution License, which permits unrestricted use, distribution, and reproduction in any medium, provided the original work is properly cited.

\begin{abstract}
Norite is a major type of solid waste generated during the production of ilmenite. This study focuses on the usability of norite as a solid precursor of alkali-activated cement. Sensitivity analysis was performed to find the influence of different alkali types and particle sizes of the source material on polycondensation. Norite was ground and mixed with sodium hydroxide and potassium hydroxide solutions to produce a binder. Potassium-containing systems were more effective compared to sodium-containing systems with respect to strength development. The X-ray diffraction patterns indicated formation of zeolites, albite, and oligoclase based on the type of activator and used additives. The patterns also revealed formation of an amorphous phase in the matrices of the binder that was cured at $87^{\circ} \mathrm{C}$. Microstructure analysis revealed some degree of crystallization with different $\mathrm{Si}$ : $\mathrm{Al}$ ratios, which indicated heterogeneity of the binder matrices.
\end{abstract}

\section{Introduction}

Alkali-activated binders are a class of inorganic alkaline polymers, which are produced during the alkaline activation of silica-rich and alumina-rich materials. The reaction shows a complex process. Generally, in an alkaline medium, the bonds of $\mathrm{Si}-\mathrm{O}-\mathrm{Si}$ are broken and aluminum $(\mathrm{Al})$ atoms penetrate into the original $\mathrm{Si}-\mathrm{O}-\mathrm{Si}$ structure. Consequently, aluminosilicate gels (oligomers) are formed and finally polycondensation takes place. Cations (e.g., $\mathrm{Na}^{+}, \mathrm{K}^{+}$, and $\mathrm{Ca}^{+}$) must be present in the framework cavities to balance the negative charges of ions $[1,2]$. The result is a cementitious phase with high mechanical strength and high fire and acid resistance. Polycondensation depends on parameters such as chemical and mineralogical composition, particle size, and surface area of the source materials. In addition, curing pressure and temperature, $\mathrm{Si}: \mathrm{Al}$ ratio of the used substances (the active silica content), alkali type (e.g., $\mathrm{NaOH}$, $\mathrm{KOH}$ ), alkali concentration, liquid-to-solid ratio, and types of additives significantly influence the binder synthesis [3-8].

Based on the source used, different types of binders can be produced such as fly ash-based and blast furnace slag-based binders. Utilization of fly ashes in the production of binders has been extensively studied $[9,10]$. However, few studies have been carried out on the usability of natural rocks to make binders in alkaline media.

One of the world's largest ilmenite producers has its quarry on the southwest coast of Norway. The mine is operated by Titania AS and the facility uses different methods to separate ilmenite from ore. The facility produces 850,000 metric tons of ilmenite concentrate per year. Ilmenite is a mineral chemically described as $\mathrm{FeTiO}_{3}$. When the iron is removed, the final product becomes $\mathrm{TiO}_{2}$ which is known as "titanium white," a widely used white pigment. Normally, ilmenite is found in large quantities in the anorthosite or norite rocks. Thus, norite or anorthosite must be separated from the valuable ilmenite. This can be done by conventional separation techniques that leave large amounts of ground norite and anorthosite particles as a waste stream. Norite is one of the main waste tailings during the production of ilmenite at Titania AS. The norite used in this study was supplied by Titania AS.

Norite is an intrusive igneous rock and is predominantly composed of orthopyroxene and plagioclase. Orthopyroxene 
TABLE 1: Chemical composition of norite (wt.\%).

\begin{tabular}{ccccccccccccccc}
\hline $\mathrm{SiO}_{2}$ & $\mathrm{TiO}_{2}$ & $\mathrm{Al}_{2} \mathrm{O}_{3}$ & $\mathrm{Fe}_{2} \mathrm{O}_{3}$ & $\mathrm{MgO}$ & $\mathrm{CaO}$ & $\mathrm{Na}_{2} \mathrm{O}$ & $\mathrm{MnO}$ & $\mathrm{K}_{2} \mathrm{O}$ & $\mathrm{P}_{2} \mathrm{O}_{5}$ & $\mathrm{Cr}_{2} \mathrm{O}_{3}$ & $\mathrm{SO}_{3}$ & $\mathrm{LOI}$ \\
\hline 43 & 8.2 & 15.5 & 12.5 & 6.8 & 6.6 & 3.4 & 0.1 & 0.9 & 0.3 & 0.03 & 0.1 & 2.57 \\
\hline
\end{tabular}

TABLE 2: Traced minerals in the norite.

\begin{tabular}{|c|c|}
\hline Minerals & Mass $\%$ \\
\hline Plagioclase $[(\mathrm{Na}, \mathrm{Ca}, \mathrm{Al})$-silicates $]$ & 64 \\
\hline Hyperstone $[(\mathrm{Ca}, \mathrm{Mg}, \mathrm{Fe}, \mathrm{Al})$-silicates] & 10 \\
\hline Biotite $[(\mathrm{K}, \mathrm{Mg}, \mathrm{Al})$-silicates $]$ & 7 \\
\hline Other silicates & 5 \\
\hline Ilmenite $\left[\mathrm{FeOTiO}_{2}\right]$ & 13 \\
\hline Sulfides & 0.5 \\
\hline Apatite $\left[\mathrm{Ca}\left(\mathrm{PO}_{4}\right)_{3}(\mathrm{~F}, \mathrm{Cl}, \mathrm{OH})\right]$ & 0.5 \\
\hline
\end{tabular}

TABLE 3: Chemical composition of GGBFS (wt.\%).

\begin{tabular}{cccccccc}
\hline $\mathrm{SiO}_{2}$ & $\mathrm{Al}_{2} \mathrm{O}_{3}$ & $\mathrm{CaO}$ & $\mathrm{MgO}$ & $\mathrm{TiO}_{2}$ & $\mathrm{Mn}_{2} \mathrm{O}_{3}$ & $\mathrm{~S}^{2-}$ & $\mathrm{Na}_{2} \mathrm{O}$ \\
\hline 34 & 13 & 31 & 17 & 2.4 & 0.6 & 1.1 & 0.9 \\
\hline
\end{tabular}

is an inosilicate and therefore has interlocking chains of silicate tetrahedra. Plagioclase is a common series of aluminosilicate (tectosilicate) minerals within the feldspar family. In the Streckeisen classification system, norite is in the group with gabbro and anorthosite. Similar to gabbro and anorthosite, norite is very rich in plagioclase compared to Kfeldspar, feldspathoids, and quartz $[11,12]$. Therefore, norite has the potential to be utilized as a solid precursor in the development of a new cementitious binder. The current study presents a fundamental procedure for developing a noritebased binder in alkali media.

\section{Experimental Program}

2.1. Materials. Titania AS provided the norite; its chemical analysis and the traced minerals are presented in Tables 1 and 2. The laboratory at Titania AS reported a $\mathrm{pH}$ value of 6.5 for the norite [13]. Sodium hydroxide $(\mathrm{NaOH})$ and potassium hydroxide $(\mathrm{KOH})$ pellets used for the preparation of alkali solutions were caustic soda and caustic potash with $99 \%$ purity. Sodium silicate solution $\left(\mathrm{Na}_{2} \mathrm{SiO}_{3}\right)$ and potassium silicate solution $\left(\mathrm{K}_{2} \mathrm{SiO}_{3}\right)$ were used in some mix designs. The $\mathrm{Na}_{2} \mathrm{SiO}_{3}$ (supplied by Merck KGaA in Germany) was reported to contain $28.5 \% \mathrm{SiO}_{2}, 8.5 \% \mathrm{Na}_{2} \mathrm{O}$, and $63 \%$ $\mathrm{H}_{2} \mathrm{O}$; the $\mathrm{K}_{2} \mathrm{SiO}_{3}$ (supplied by Univar AS, Norway) was reported to contain $38 \%$ potassium silicate and $62 \% \mathrm{H}_{2} \mathrm{O}$. An aluminum- and calcium-rich blast furnace slag (product name "Merit 5000" from Merit 5000, Sweden) was used as an additive (Table 3 ). Distilled water was used throughout the experiments.

2.2. Test and Analysis Methods. As the norite particle size was high, $0.4-2 \mathrm{~mm}$, the specific surface area of the norite was increased to enhance its reactivity by milling. Therefore, every $100 \mathrm{~g}$ of the norite was ground by using a Retsch PM100 ball mill at $356 \mathrm{rpm}$ for 10 minutes. Particle size distribution
(PSD) of the ground norite, Figure 1, was measured using a Sympatec HELOS laser diffraction particle size analyzer. The analysis was done at Tel-Tek National Research Institute, Norway. Sauter mean diameter (SMD) and volume mean diameter (VMD) were reported to be 6.43 and $47.16 \mu \mathrm{m}$, respectively. The particle density of norite was estimated to be $2.00 \mathrm{~g} / \mathrm{cc}$.

A Zeiss Supra 35VP model scanning electron microscopy-energy dispersive X-ray spectroscopy (SEM-EDXS) analyzer was used. The analysis was performed at ambient temperature and under high vacuum conditions.

An Agilent Cary 630 FTIR (Fourier transform infrared) spectrometer was used to investigate the structure of the norite and the investigation was carried out in the 1200$400 \mathrm{~cm}^{-1}$ region. The $\mathrm{KBr}$ (potassium bromide) wafer technique was used for the spectra determination [2].

$\mathrm{X}$-ray powder diffraction (XRD) analysis of the norite and the binder was performed using $\mathrm{X}$-ray synchrotron radiation with the wavelength of $0.6888 \AA$. The XRD measurements were performed with a PILATUS2M pixel detector-based diffractometer at the Swiss-Norwegian beamline (SNBLBM01A), at the European Synchrotron Radiation Facility, ESRF, Grenoble, France. The two-dimensional diffraction patterns spanned a maximal diffraction angle, $2 \theta$, of 46 degrees. One-dimensional diffraction patterns were obtained by azimuth integration using the program Fit2D [14]. The mineral analysis program, Match!, and Crystallography Open Database (COD) were used for phase identification [15].

To measure the compressive strength of the binder, two different uniaxial compressive strength (UCS) mechanical testers were utilized: a Zwick/Z020 for specimens with compressive strength lower than $10 \mathrm{MPa}$ and a Toni Technik- $\mathrm{H}$ for specimens with compressive strength higher than $10 \mathrm{MPa}$. The Zwick/Z020 and Toni Technik-H testers applied TestXpert II v3.2 and TestXpert v7.11 testing software, respectively, to calculate UCS of the specimens.

2.3. Specimen Preparation. In order to produce a pure noritebased binder, the ground norite was mixed with an alkali solution for 2 minutes. To investigate the influences of ground granulated blast furnace slag (GGBFS) and type of alkali silicate solution, the GGBFS and alkali silicate solution were introduced into some of the mixes as presented in Tables 4 and 5. When an alkali silicate solution was required, the alkali solution and the alkali silicate solution were mixed prior to adding the solid phase. Whenever the GGBFS was necessary, it was entered into the blend during the final part of the mixing. A Hamilton Beach blender was used for the mixing.

The slurries were poured in cylindrical plastic molds with $52 \mathrm{~mm}$ diameter and $100 \mathrm{~mm}$ length. The specimens were cured at ambient pressure and different temperatures: ambient temperature and $87^{\circ} \mathrm{C}$. Tables 4 and 5 present the mix designs. 
TABLE 4: Compressive strength of the binders without any additives. The specimens were cured at $87^{\circ} \mathrm{C}$ and ambient pressure.

\begin{tabular}{lccccc}
\hline $\begin{array}{l}\text { Norite } \\
(\mathrm{g})\end{array}$ & Alkali sol. & Wt. of alkali sol. $(\mathrm{g})$ & L/S ratio & $\begin{array}{c}\text { Specimen } 1 \\
\text { Curing time } \\
(\text { days })\end{array}$ & $\begin{array}{c}\text { Estimated compressive strength } \\
( \pm 2 \mathrm{MPa})\end{array}$ \\
\hline 300 & $8 \mathrm{M} \mathrm{NaOH}$ & 125 & 0.42 & 5 & 2.5 \\
300 & $8 \mathrm{M} \mathrm{NaOH}$ & 125 & 0.42 & 7 & 3 \\
300 & $8 \mathrm{M} \mathrm{NaOH}$ & 125 & 0.42 & 14 & 23 \\
300 & $8 \mathrm{M} \mathrm{NaOH}$ & 125 & 0.42 & 28 & 24 \\
\hline
\end{tabular}

TABLE 5: Influence of GGBFS on the compressive strength of the binder. The specimens were cured at ambient pressure.

\begin{tabular}{|c|c|c|c|c|c|c|c|c|c|c|}
\hline Specimen & $\begin{array}{l}\text { Norite } \\
(\mathrm{g})\end{array}$ & $\begin{array}{c}\text { GGBFS } \\
(\mathrm{g})\end{array}$ & Alkali sol. & $\begin{array}{l}\text { Wt. of alkali } \\
\text { sol. (g) }\end{array}$ & $\begin{array}{l}\mathrm{K}_{2} \mathrm{SiO}_{3} \\
\quad(\mathrm{~g})\end{array}$ & $\begin{array}{c}\mathrm{Na}_{2} \mathrm{SiO}_{3} \\
\text { (g) }\end{array}$ & $\begin{array}{l}\mathrm{L} / \mathrm{S} \\
\text { ratio }\end{array}$ & $\begin{array}{l}\text { Curing } \\
\text { temp. } \\
\left({ }^{\circ} \mathrm{C}\right)\end{array}$ & $\begin{array}{l}\text { Curing } \\
\text { time } \\
\text { (days) }\end{array}$ & $\begin{array}{l}\text { Estimated } \\
\text { compressive } \\
\text { strength } \\
( \pm 2 \mathrm{MPa})\end{array}$ \\
\hline 2 & 183 & 91 & $8 \mathrm{M} \mathrm{NaOH}$ & 52 & 0 & 72 & 0.45 & 23 & 7 & 20 \\
\hline 3 & 183 & 91 & $4 \mathrm{M} \mathrm{KOH}$ & 53 & 72 & 0 & 0.46 & 23 & 7 & 26 \\
\hline 4 & 248 & 40 & $10 \mathrm{M} \mathrm{NaOH}$ & 61 & 61 & 0 & 0.42 & 87 & 1 & 5.0 \\
\hline 4 & 248 & 40 & $10 \mathrm{M} \mathrm{NaOH}$ & 61 & 61 & 0 & 0.42 & 87 & 5 & 9.0 \\
\hline 4 & 248 & 40 & $10 \mathrm{M} \mathrm{NaOH}$ & 61 & 61 & 0 & 0.42 & 87 & 7 & 9.0 \\
\hline
\end{tabular}

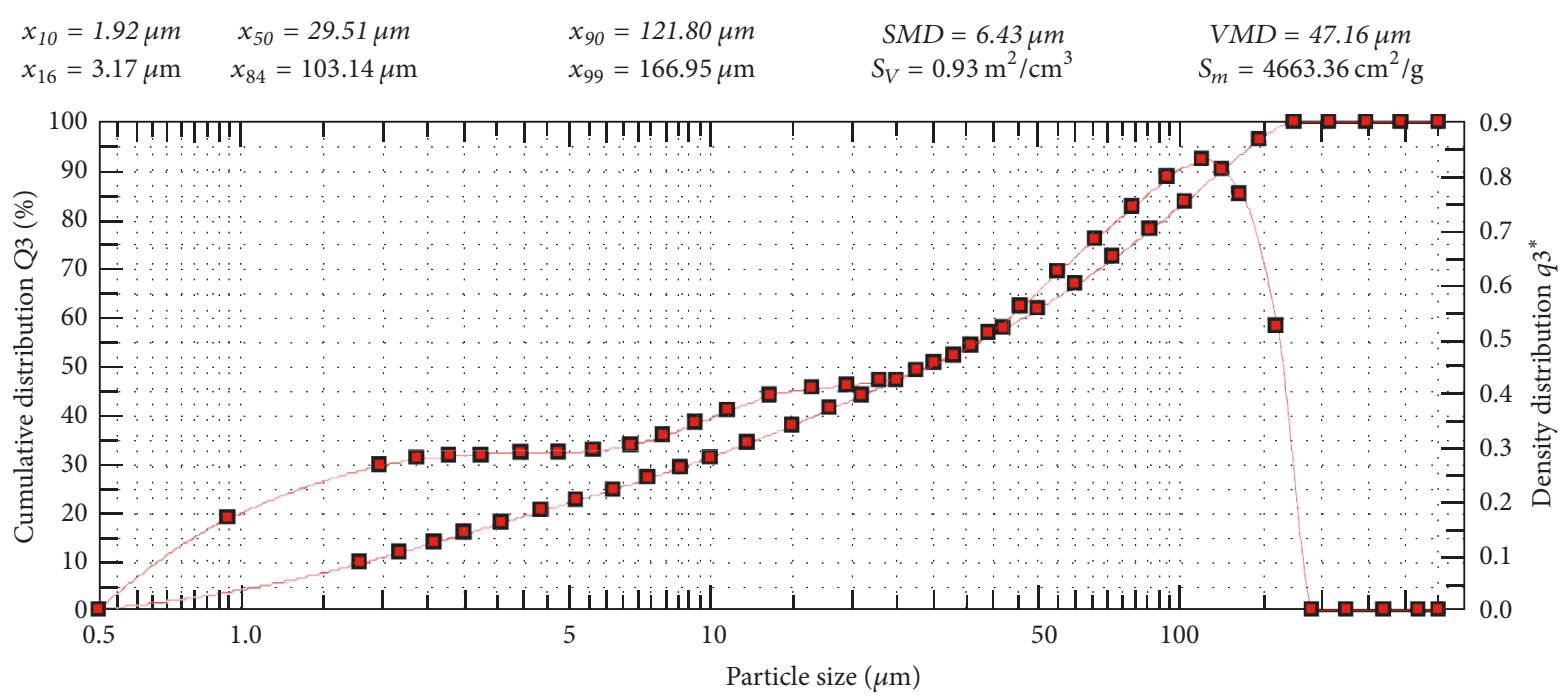

FIGURE 1: Graphical representation of particle size distribution analysis of the analyzed norite.

\section{Results and Discussion}

For a better understanding of the binder synthesis, sets of analytical experiments were conducted. For each test, only one parameter was changed while the others were kept constant. The compressive strength of the different specimens was measured, besides the XRD and microstructure analyses.

3.1. Effect of Particle Size. The norite particle size could be important for understanding its physical and chemical properties. So, two specimens were prepared to evaluate the influence of the norite particle size on its reactivity. The specimens were prepared by using the nonground and the ground norite. The maximum particle size of the nonground norite was reported to be $2 \mathrm{~mm}$. Both specimens were mixed by using $8 \mathrm{M} \mathrm{NaOH}$ and cured at ambient pressure and temperature for 7 days. A liquid-to-solid mass ratio of 0.42 was selected to maintain fluidity of the slurries; however, generally, a liquid-to-solid mass ratio of 0.35 is recommended [16]. The prepared slurry with the nonground norite never solidified while the ground norite solidified (Figure 2). Although the larger precursor particles have lower surfaceto-volume ratio and the slurry requires a lower activator content, the formation of gels was not observed. The smaller the particle sizes, the higher the reactivity of the norite. Likely, the large particles do not participate in the reaction to form the binder but they act as an aggregate (Figure 4(a)). It could be said that milling activates the material mechanically. 


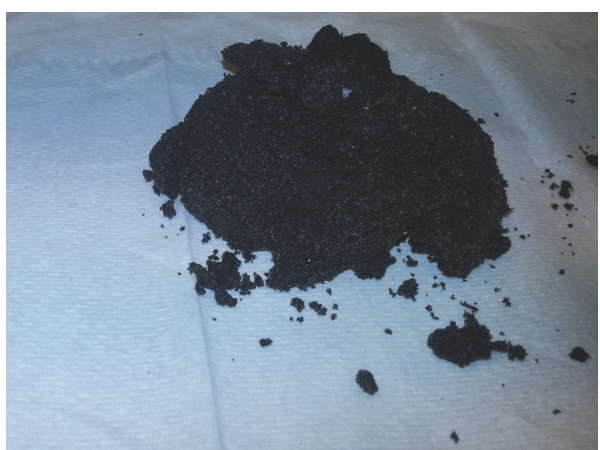

(a)

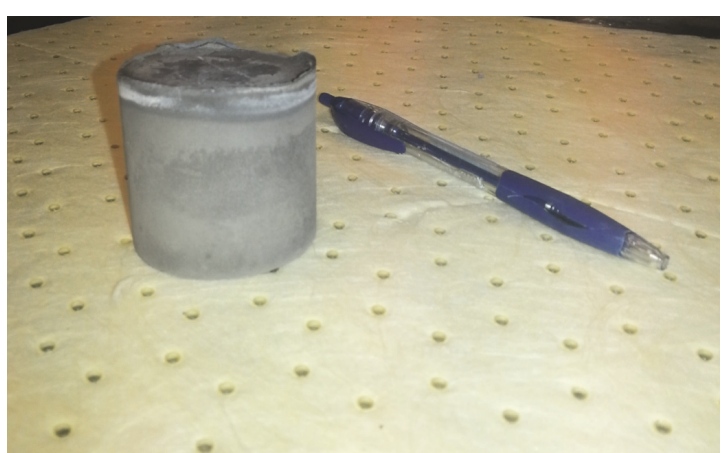

(b)

FIgURE 2: Effect of particle size on the reactivity at $87^{\circ} \mathrm{C}$ and ambient pressure: (a) nonground norite and (b) ground norite.

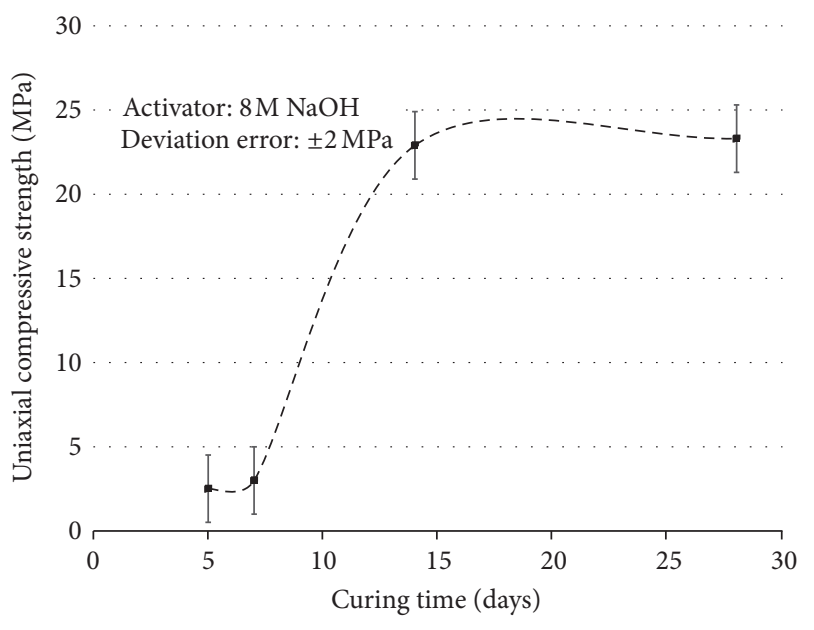

FIGURE 3: Strength development of specimen 1 at $87^{\circ} \mathrm{C}$ and ambient pressure.

Figure 3 presents the compressive strength development of the norite-based binder, which was cured at $87^{\circ} \mathrm{C}$ and ambient pressure. A radical strength development was observed after 7 days of curing. The specimens were prepared by mixing the norite with $8 \mathrm{M}$ solution of sodium hydroxide (Table 4).

\subsection{Microstructure Analysis of the Binder}

3.2.1. Scanning Electron Microscopy (SEM). Figure 4 presents the SEM images of specimen 1 , which was cured at $87^{\circ} \mathrm{C}$ and ambient pressure for 7 days. The crystallization is shown through Figures 4(a)-4(c). Two crystals were selected for element analysis to confirm the polycondensation. The crystals are marked with a green cross (Figures 4(b)-4(c)). The resulting crystals mainly contain $\mathrm{Si}, \mathrm{Al}, \mathrm{O}$, and $\mathrm{Na}$. The element analysis of the marked crystals resembled erionite and oligoclase. From microstructural observations, it could be said that the selected matrices are not homogeneous (Figures 4(b)-4(c)). One crystal has a $\mathrm{Si}$ : Al ratio of 1.5 (Figure 4(b)), while the other crystal has a Si : Al ratio of 2 (Figure 4(c)). Higher magnifications on the crystals showed existence of some fissures as shown in Figure 4(b).
As shown in Figure 4(b), some rod-like species have been identified in some parts of the binder. The influence of these rod-like species on the compressive strength could not be figured out and, in this regard, further studies should be carried out in the future.

3.2.2. X-Ray Diffraction Analysis. Figure 5 shows the XRD patterns of the binder cured for 7 days at $87^{\circ} \mathrm{C}$ and ambient pressure. The XRD analysis shows that the starting material mainly consists of anorthite sodian $\left(\mathrm{Al}_{1.52} \mathrm{Ca}_{0.52} \mathrm{Na}_{0.48} \mathrm{O}_{8} \mathrm{Si}_{2.48}\right)$. But erionite, albite, and stilbite$\mathrm{Na}$ seem to be synthesized as a result of polycondensation. In addition, the formation of an amorphous phase was noticed as a broad diffuse halo, or a "hump," in the $2 \theta$ range between 5 and $15^{\circ}$. Nonetheless, it has been shown that amorphous inorganic polymers are formed in the $2 \theta$ range between 20 and 39 degrees. The identification of the amorphous phases requires further study.

The XRD patterns show that when the norite was mixed with pure $8 \mathrm{M} \mathrm{NaOH}$ solution, the content of the amorphous phase increased (Figure 5(a)). He et al. [17] reported that curing alkali-activated based slurries at elevated temperatures leads to a higher degree of crystallization. It should be mentioned that, for the K-containing system, the pattern showed lower content of the amorphous phase compared to the Na-containing system. However, the GGBFS used as an additive was almost amorphous.

The oligoclase determined by the XRD patterns $\left(\mathrm{Al}_{1.277} \mathrm{Ca}_{0.277} \mathrm{Na}_{0.723} \mathrm{Si}_{2.723}\right)$ with low content of erionite-Ca $\left(\mathrm{Al}_{3.954} \mathrm{Ca}_{1.22} \mathrm{H}_{72.096} \mathrm{~K}_{6} \mathrm{Mg}_{0.26} \mathrm{O}_{49.2} \mathrm{Si}_{14.046}\right)$ was the reaction product of a Na-containing system (Figure 5(a)). Oligoclase is a high sodium content feldspar which could be reasonable due to the use of Na-containing solution [12]. Erionite-Ca is a member of the zeolite minerals. Gougazeh and Buhl [18] studied the synthesis of zeolite A by treating the activated metakaolin from natural kaolin with various concentrations of $\mathrm{NaOH}$ at $100^{\circ} \mathrm{C}$. Their result shows that zeolite A was the major constituent phase, while quartz and hydroxysodalite were the minor constituents of the final product.

Further, the patterns show that albite $\left(\mathrm{AlNaO}_{8} \mathrm{Si}_{3}\right)$ and stilbite- $\mathrm{Na}\left(\mathrm{Al}_{2.42} \mathrm{Ca}_{0.84} \mathrm{H}_{18} \mathrm{Na}_{0.75} \mathrm{O}_{24.12} \mathrm{Si}_{6.64}\right)$ are the reaction products for the K-containing system (Figure 5(b)). Albite is a plagioclase feldspar mineral and stilbite is a series of 


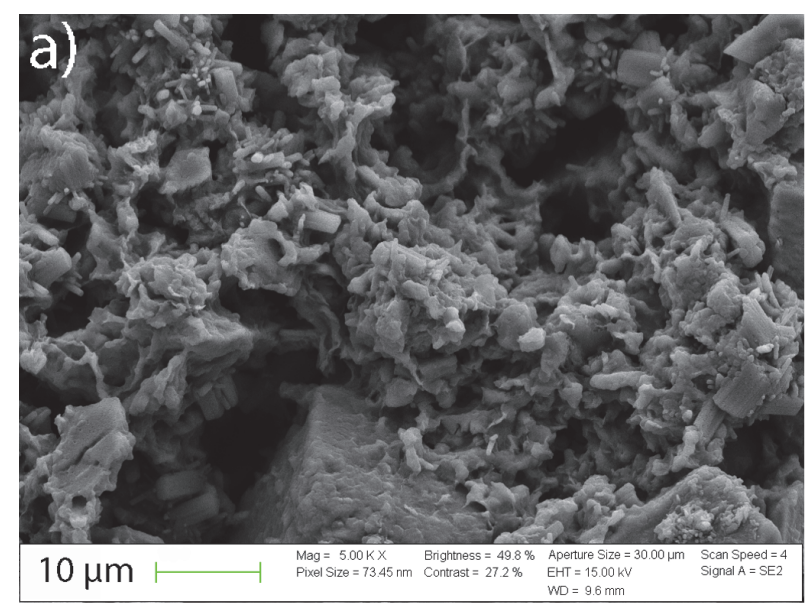

(a)

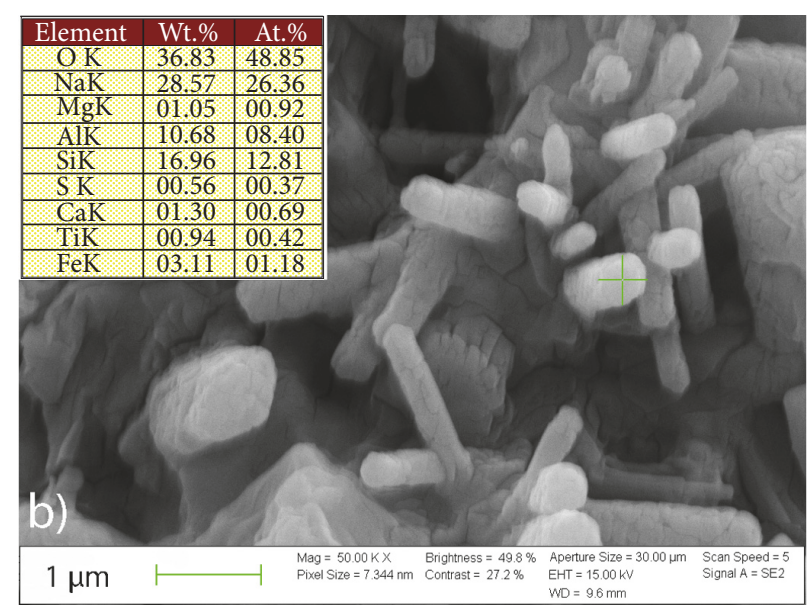

(b)

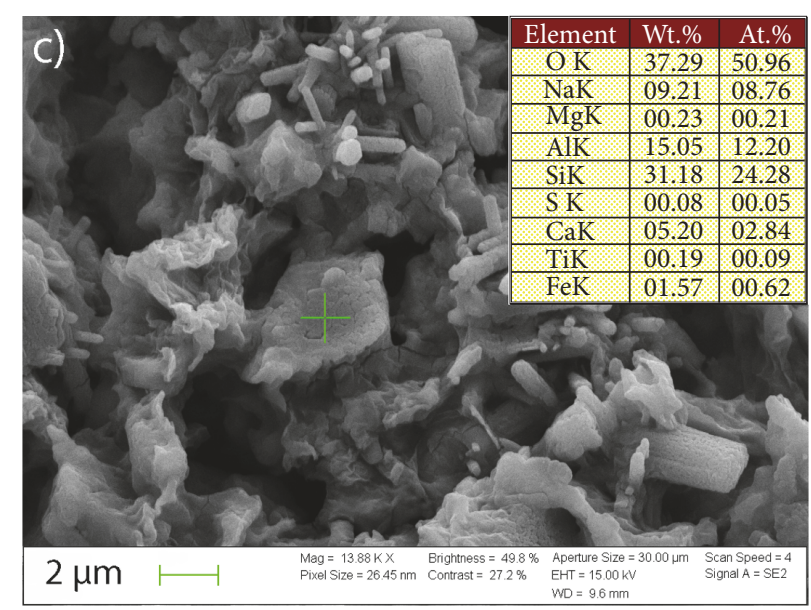

(c)

FIGURE 4: SEM images of specimen 1 cured for 7 days at $87^{\circ} \mathrm{C}$ and ambient pressure; (a) pores are visible; (b) needle structures; (c) elemental analysis of a selected point.

tectosilicate minerals of the zeolite group. Kawano and Tomita [19] reported the synthesis of zeolites from obsidian in various concentrations of $\mathrm{NaOH}$ and $\mathrm{KOH}$ solutions at 150 and $200^{\circ} \mathrm{C}$. They showed that smectite, phillipsite, and rhodesite formed in an $\mathrm{NaOH}$ solution as $\mathrm{pH}$ increased and smectite, merlinoite, and sanidine were produced in $\mathrm{KOH}$ solutions as $\mathrm{pH}$ increased. The $\mathrm{pH}$ and $\mathrm{Si}: \mathrm{Al}$ and $\mathrm{Na}$ : $\mathrm{K}$ ratios of the reacting solutions were important parameters determining the nature of the products formed from obsidian. Formation of the zeolite could be due to the quantity of silica and grain size as investigated by Prudhomme et al. [20].

3.2.3. Infrared Analysis (IR). The infrared spectra of the norite and the norite-based binder are given in Figure 6. The binder was cured for 7 days at $87^{\circ} \mathrm{C}$ and ambient pressure. As shown in Figure 6, the chemical shifts of main IR characteristic bands and appearance of new peaks were observed. The IR for the solid precursors (norite) and the binder consists of the strongest vibrations at $980-1020 \mathrm{~cm}^{-1}$ and $420-560 \mathrm{~cm}^{-1}$. Comparing the IR spectra of the norite and norite-based binder shows that, during polycondensation, the outstanding band at $1008 \mathrm{~cm}^{-1}$ shifted towards a lower wavenumber $\left(1000 \mathrm{~cm}^{-1}\right)$. It seems that $1008 \mathrm{~cm}^{-1}$ band is caused by asymmetrical vibration of $\mathrm{Si}(\mathrm{Al})-\mathrm{O}$ bonds and $540 \mathrm{~cm}^{-1}$ band by bending vibration of Si-O-Al bonds [2, 21]. The appearance of new peaks at 881 and $577 \mathrm{~cm}^{-1}$ is due to reaction. Mucsi et al. [22] studied the formation of fly ash-based geopolymer by using Fourier transformed infrared (FTIR) spectroscopy and suggested that the appearance of a new peak at $881 \mathrm{~cm}^{-1}$ is related to $\mathrm{Si}-\mathrm{O}$ stretching and the bending of $\mathrm{O}-\mathrm{H}$ in the $\mathrm{Si}-\mathrm{OH}$ bond.

3.3. Influence of the GGBFS on the Compressive Strengths. Inclusion and influence of GGBFS on fly-ash have been studied on the setting time and strength development of fly ash-based binder. It is believed that addition of an amorphous silica phase leads to a shorter setting time and higher compressive strength. It has also been reported that the addition of GGBFS to concrete enhances setting time of concrete at ambient temperature. However, it may affect the 


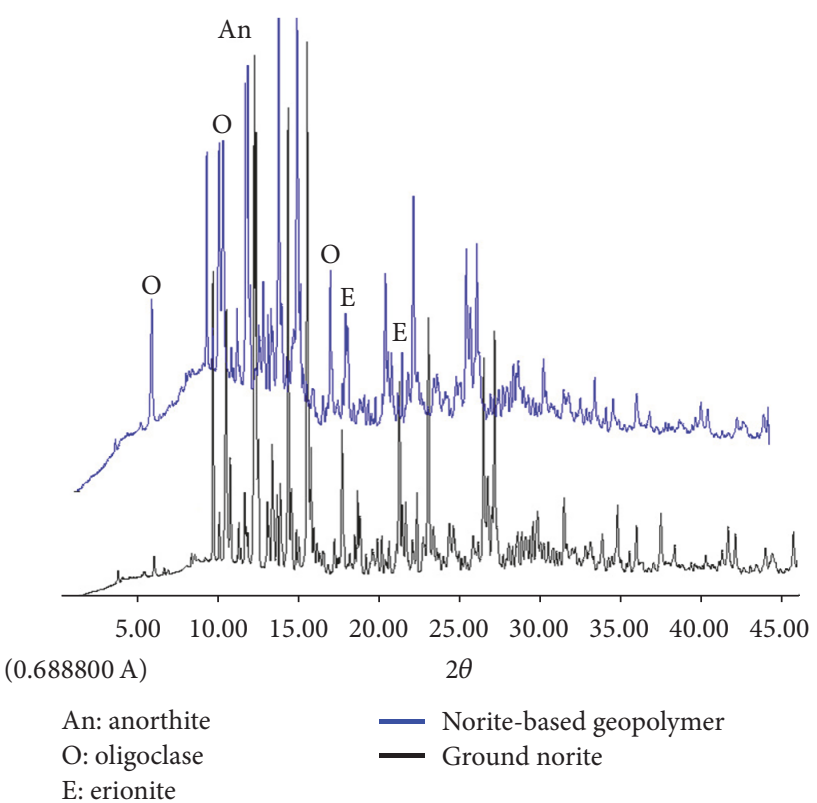

(a) Specimen 1: Na-containing system, amorphous phase as a broad diffuse halo in the $2 \theta$ range between 5 and $15^{\circ}$

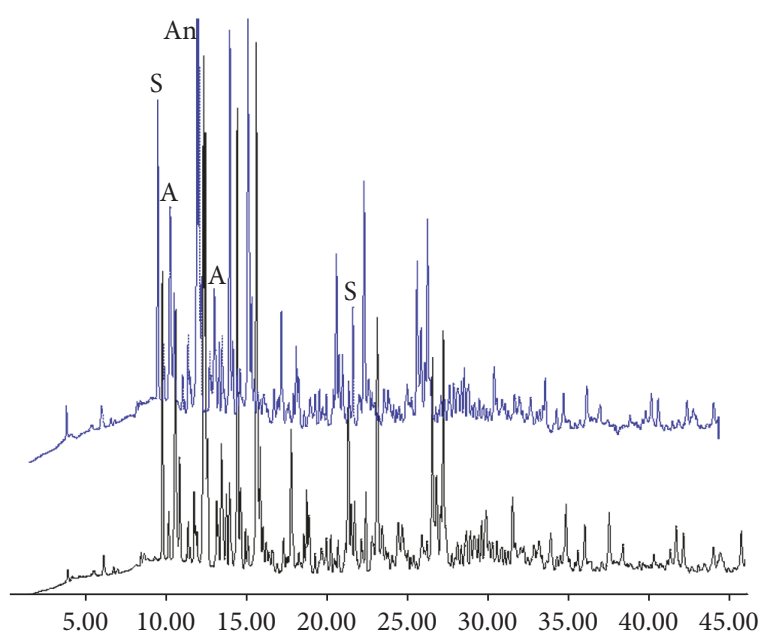

$(0.688800 \mathrm{~A})$

$2 \theta$

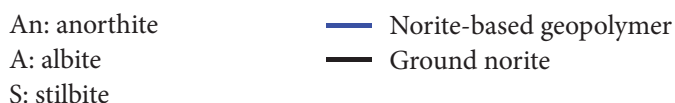

(b) Specimen 4: K-containing system with GGBFS, lower content of amorphous phase in the $2 \theta$ range between 5 and $15^{\circ}$

FIgURE 5: X-ray patterns of the norite-based binders cured for 7 days at $87^{\circ} \mathrm{C}$ and ambient pressure.

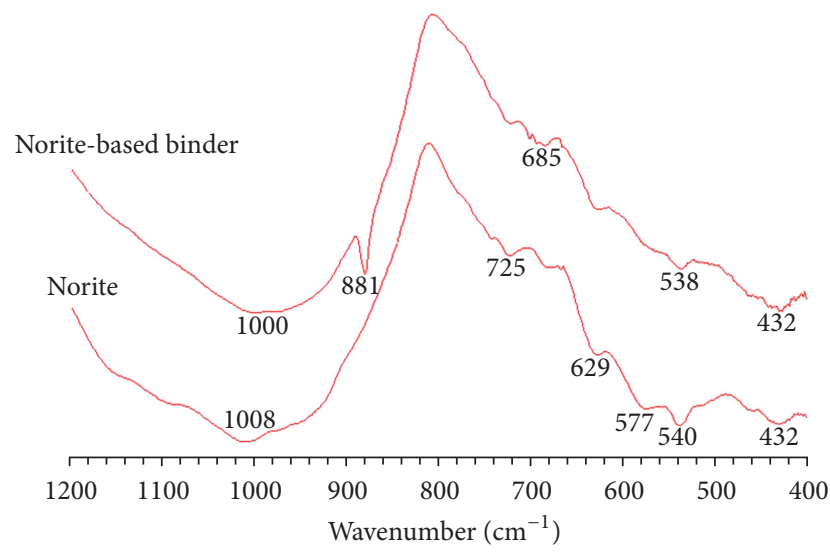

FIGURE 6: FTIR of aluminosilicates of the solid precursor and the norite-based binder, which was cured for 7 days at $87^{\circ} \mathrm{C}$ and ambient pressure.

final compressive strength of the slurry due to incomplete reaction $[16,23]$.

As the measured 7-day compressive strength of the binder was low, the influence of GGBFS was studied. As shown in Table 5, addition of the GGBFS to the slurries strongly influenced the compressive strength of the specimens, which were cured at ambient pressure and temperature. However, there was no supplementary information about the hydraulic reactivity relation for the used GGBFS.

3.4. Effect of Alkali Solution. The influence of alkali type was studied in this work. The obtained results show higher compressive strength for the specimens prepared using
K-containing systems than with sodium (Table 5). It has been reported that dissolution of aluminosilicate in a sodium solution is more effective than in a potassium solution. However, the compressive strength of the binder is higher for the Kcontaining systems than for the Na-containing systems $[2,24$, 25]. This phenomenon is explained by the size of $\mathrm{K}^{+}$cations and the formation of zeolite in the geopolymer structure [26]. Therefore, to get the same strength as the K-containing system, the amount of sodium solution may be increased. The used concentrations are classified as corrosive in the criteria for classification of substances; therefore, the K-containing system may have a lower risk of hazard, which makes it userfriendly. Hence, it could be said that K-containing systems are more user-friendly in comparison to Na-containing systems. However, a combination of potassium and sodium solutions substantially reduces the compressive strength (Table 5).

\section{Conclusion}

A norite-based binder has been successfully produced from the waste tailing of an ilmenite mine consisting mainly of anorthosite. The particle size of the source material significantly affected the reactivity. The IR spectra of noritebased binder showed a shift towards a lower wavenumber. The maximum compressive strength was obtained for the fully potassium-containing system while a combination of sodium and potassium reduced the strength development. The XRD patterns showed formation of oligoclase, albite, and zeolites. Furthermore, the patterns indicated amorphous phases for the Na-containing systems at $87^{\circ} \mathrm{C}$ of curing; however, crystallization was expected at elevated temperatures. The SEM images showed some degree of crystallization and heterogeneity in the binder matrices. 


\section{Conflicts of Interest}

The authors declare that there are no conflicts of interest regarding the publication of this paper.

\section{Acknowledgments}

The authors acknowledge the Research Council of Norway, ConocoPhillips, AkerBP, Statoil, and Wintershall for financing the work through the research center DrillWell (Drilling and Well Centre for Improved Recovery), research cooperation between IRIS, NTNU, SINTEF, and UiS. The authors are also grateful to the management of Titania AS, Norway, for their support. Special thanks are due to the SwissNorwegian beamlines (SNBL) at the European Synchrotron Radiation Facility (ESRF) for providing beamtime and technical support during the experiment.

\section{References}

[1] F. Pacheco-Torgal, J. A. Labrincha, C. Leonelli et al., Handbook of Alkali-activated Cements, Mortars and Concretes, Oxford: Woodhead Publishing, Oxford, UK, 5th edition, 2014.

[2] J. Davidovits, Geopolymer Chemistry and Application, SaintQuentin: Institut Geopolymere, Saint-Quentin, France, 3rd edition, 2011.

[3] I. Garcia-Lodeiro, A. Fernández-Jimenez, P. Pena, and A. Palomo, "Alkaline activation of synthetic aluminosilicate glass," Ceramics International, vol. 40, no. 4, pp. 5547-5558, 2014.

[4] D. L. Y. Kong, J. G. Sanjayan, and K. Sagoe-Crentsil, "Factors affecting the performance of metakaolin geopolymers exposed to elevated temperatures," Journal of Materials Science, vol. 43, no. 3, pp. 824-831, 2008.

[5] E. I. Diaz, E. N. Allouche, and S. Eklund, "Factors affecting the suitability of fly ash as source material for geopolymers," Fuel, vol. 89, no. 5, pp. 992-996, 2010.

[6] J. Nemecek, V. Smilauer, and L. Kopecky, "Nanoindentation characteristics of alkali-activated aluminosilicate materials," Cement and Concrete Composites, vol. 33, pp. 163-170, 2011.

[7] J. Stark, "Recent advances in the field of cement hydration and microstructure analysis," Cement and Concrete Research, vol. 41, pp. 666-678, 2011.

[8] D. Ravikumar, S. Peethamparan, and N. Neithalath, "Structure and strength of $\mathrm{NaOH}$ activated concretes containing fly ash or GGBFS as the sole binder," Cement and Concrete Composites, vol. 32, no. 6, pp. 399-410, 2010.

[9] M. Khalifeh, A. Saasen, T. Vralstad, and H. Hodne, "Potential utilization of class C fly ash-based geopolymer in oil well cementing operations," Cement and Concrete Composites, vol. 53, pp. 10-17, 2014.

[10] M. C. M. Nasvi, P. G. Ranjith, and J. Sanjayan, “The permeability of geopolymer at down-hole stress conditions: application for carbon dioxide sequestration wells," Applied Energy, vol. 102, pp. 1391-1398, 2013.

[11] H. Pichler and C. Schmitt-Riegraf, Rock-Forming Minerals in Thin Section, Chapman and Hall, london, UK, 2nd edition, 1993.

[12] W. D. Nesse, Introduction to Mineralogy, Oxford University Press, Inc, Oxford, UK, 1st edition, 2000.

[13] P. I. Norkyn, Laboratory Analysis of Norite, Kronos Titania AS, 2004.
[14] A. P. Hammersley, S. O. Svensson, M. Hanfland, A. N. Fitch, and D. Häusermann, "Two-dimensional detector software: from real detector to idealised image or two-theta scan," High Pressure Research, vol. 14, no. 4-5, pp. 235-248, 1996.

[15] Match!, Phase Identification from Powder Diffraction, Version 2, Crystal Impact, Dr. H. Putz and Dr. K. Brandenburg GbR, Kreuzherrenstr, 102, 53227 Bonn, Germany, http://www.crystalimpact.com/match.

[16] P. S. Deb, P. Nath, and P. K. Sarker, "The effects of ground granulated blast-furnace slag blending with fly ash and activator content on the workability and strength properties of geopolymer concrete cured at ambient temperature," Materials \& Design, vol. 62, pp. 32-39, 2014.

[17] P. He, D. Jia, M. Wang, and Y. Zhou, "Thermal evolution and crystallization kinetics of potassium-based geopolymer," Ceramics International, vol. 37, no. 1, pp. 59-63, 2011.

[18] M. Gougazeh and J.-C. Buhl, "Synthesis and characterization of zeolite A by hydrothermal transformation of natural Jordanian kaolin," Journal of the Association of Arab Universities for Basic and Applied Sciences, vol. 15, no. 1, pp. 35-42, 2014.

[19] M. Kawano and K. Tomita, "Experimental study on the formation of clay minerals from obsidian by interaction with acid solution at $150^{\circ}$ and $200^{\circ} \mathrm{C}, "$ Clays and Clay Minerals, vol. 43, no. 2, pp. 212-222, 1995.

[20] E. Prudhomme, P. Michaud, E. Joussein, and S. Rossignol, "Influence of raw materials and potassium and silicon concentrations on the formation of a zeolite phase in a geopolymer network during thermal treatment," Journal of Non-Crystalline Solids, vol. 358, no. 16, pp. 1908-1916, 2012.

[21] Z. Yunsheng, S. Wei, C. Qianli, and C. Lin, "Synthesis and heavy metal immobilization behaviors of slag based geopolymer," Journal of Hazardous Materials, vol. 143, no. 1-2, pp. 206-213, 2007.

[22] G. Mucsi, S. Kumar, B. Csoke et al., "Control of geopolymer properties by grinding of land filled fly ash," International Journal of Mineral Processing, vol. 143, pp. 50-58, 2015.

[23] H. Xu, W. Gong, L. Syltebo, K. Izzo, W. Lutze, and I. L. Pegg, "Effect of blast furnace slag grades on fly ash based geopolymer waste forms," Fuel, vol. 133, pp. 332-340, 2014.

[24] L. Xin, J.-Y. Xu, W. Li, and E. Bai, "Effect of alkali-activator types on the dynamic compressive deformation behavior of geopolymer concrete," Materials Letters, vol. 124, pp. 310-312, 2014.

[25] G. S. Ryu, Y. B. Lee, K. T. Koh, and Y. S. Chung, "The mechanical properties of fly ash-based geopolymer concrete with alkaline activators," Construction and Building Materials, vol. 47, pp. 409-418, 2013.

[26] M. Khalifeh, A. Saasen, T. Vrålstad, H. B. Larsen, and H. Hodne, "Experimental study on the synthesis and characterization of aplite rock-based geopolymers," Journal of Sustainable CementBased Materials, vol. 5, no. 4, pp. 233-246, 2016. 

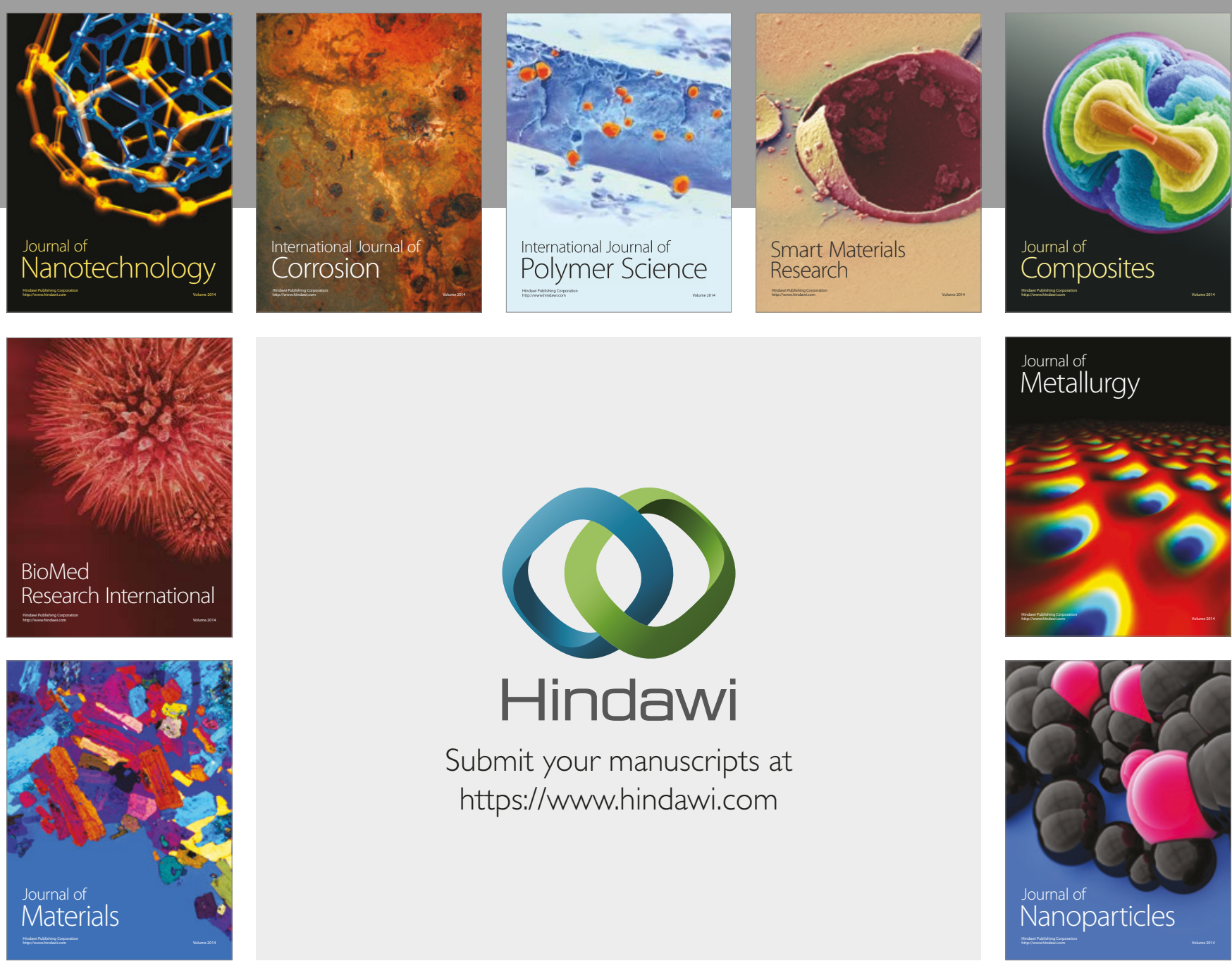

\section{Hindawi}

Submit your manuscripts at

https://www.hindawi.com
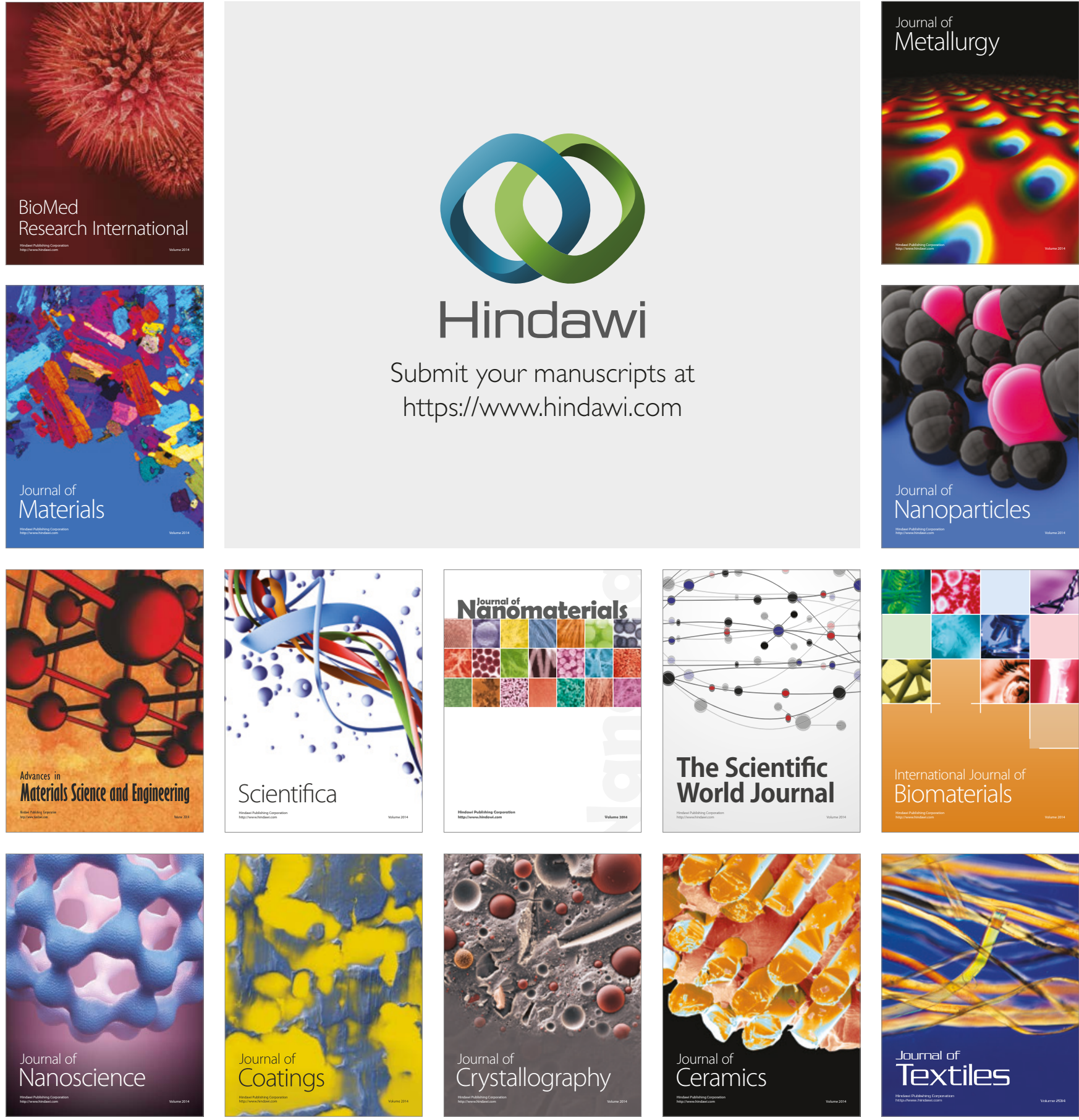

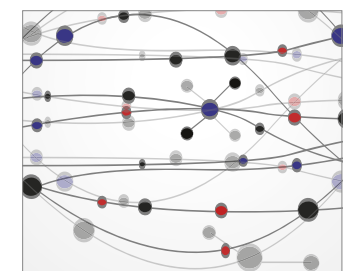

The Scientific World Journal
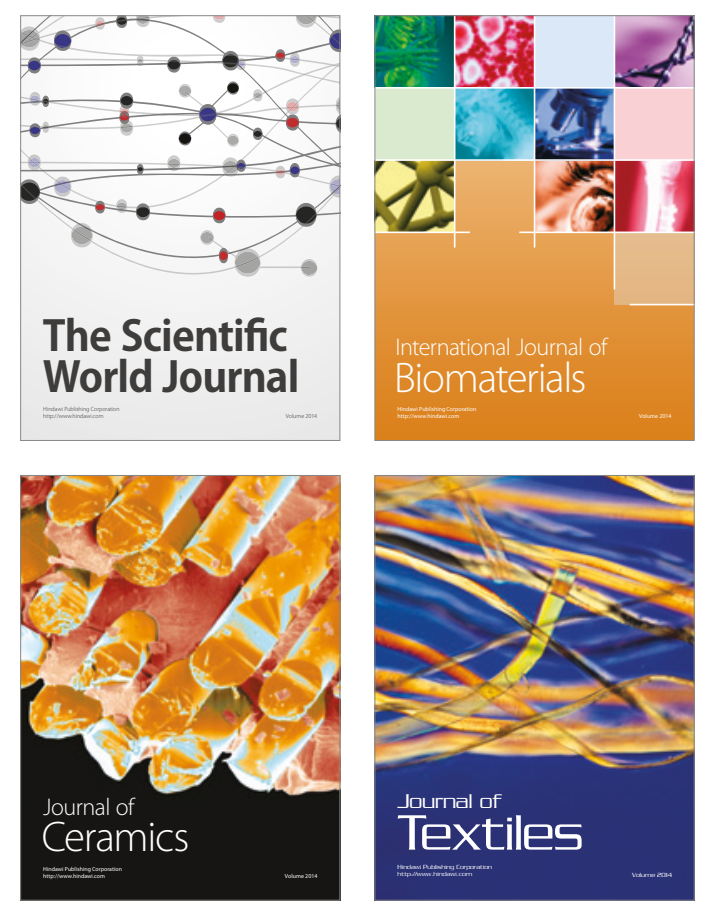